\title{
Determination of harvest time and quality of native camu-camu fruits (Myrciaria dubia (Kunth) Mc Vaugh) during storage
}

\author{
Maria Luiza Grigio ${ }^{1, \star}$, Edvan Alves Chagas ${ }^{2}$, Maria Fernanda Berlingieri Durigan ${ }^{2}$, Ataiza de Andrade \\ Sousa $^{3}$, Adamor Barbosa Mota Filho ${ }^{4}$ and Pollyana Cardoso Chagas ${ }^{5}$ \\ 1 Ph.D. student BIONORTE/UFRR, Boa Vista-RR, Brazil \\ 2 Researcher at Embrapa-RR, BR 174, km 08, PO box.133, Distrito industrial, Zip code 69301-970, Boa Vista-RR, Brazil \\ 3 Master POSAGRO/UFRR, Km 12 BR174, Zip code 69301-970, Boa Vista/RR, Brazil \\ 4 Graduating from agronomy, Km 12 BR174, Zip code 69301-970, Boa Vista/RR, Brazil \\ 5 Professor at UFRR, Km 12 BR174, Zip code 69301-970, Boa Vista/RR, Brazil
}

Received 21 June 2015 - Accepted 27 June 2016

\begin{abstract}
Introduction. Camu-camu (Myrciaria dubia (Kunth) Mc Vaugh) is a fruit species of the Myrtaceae family. It presents great economic potential due to its nutritional and antioxidant capacity and high vitamin $\mathrm{C}$ contents, reaching $7355 \mathrm{mg}$ ascorbic acid $100 \mathrm{~g}^{-1}$ pulp. The present work aimed to determine the harvest time and quality of camu-camu native fruits during storage. Materials and methods. The experiment was carried out in a completely randomized design with three replications, containing 30 fruits each, in a factorial scheme $(3 \times 8)$, composed of three different maturation stages (immature, semi-mature and mature) and eight days of storage. Fruits were evaluated every day regarding the following variables: loss of fresh mass, $\mathrm{pH}$, soluble solid contents (SS), titratable acidity (TA), ascorbic acid (AA), chlorophyll A and B content, and the maturation index (SS:TA). Results and discussion. Fruits at the semimature stage presented the greatest amount of ascorbic acid, conserving the quality attributes (SS, AT and fresh mass) and the ascorbic acid contents for longer. Fruits at the immature stage presented the highest values for chlorophylls A and $\mathrm{B}$, and this stage is also recommended for the extraction of these biocompounds. Conclusion. The recommended harvest time of the camu-camu fruit is the semi-mature stage, when the fruit presents better quality and a longer shelf life, and conserves the desired nutritional values for longer.
\end{abstract}

Keywords: Brazil / Amazon Rainforest / camu-camu / Myrciaria dubia / fruit quality / ascorbic acid / maturation stage / postharvest management

Résumé - Détermination du stade de récolte de la qualité des fruits du camu-camu sauvage (Myrciaria dubia (Kunth) McVaugh) en cours de stockage. Introduction. Le camu-camu est une espèce fruitière de la famille des Myrtacées. Elle présente un fort potentiel économique en raison des propriétés nutritionnelles et antioxydantes et de la haute teneur en vitamine $\mathrm{C}$ de la pulpe de ses fruits, atteignant $7,355 \mathrm{mg}$ acide ascorbique $100 \mathrm{~g}^{-1}$. Le présent travail vise à déterminer le stade de récolte et la qualité des fruits du camu-camu sauvage au cours du stockage. Matériel et méthodes. L'expérience a été réalisée selon un dispositif complètement aléatoire à trois répétitions comprenant 30 fruits chacune, dans un schéma factoriel $(3 \times 8)$ composé de trois étapes de mûrissement (fruit immature, semi-mature et mûr), et de huit jours de stockage. Les fruits ont été évalués tous les jours selon les variables suivantes : perte de masse fraîche, $\mathrm{pH}$, teneur en matières solubles (SS), acidité titrable (TA), teneur en acide ascorbique (AA), en chlorophylles A et B, et indice de maturation (rapport SS:TA). Résultats et discussion. Les fruits au stade semi-mature ont présenté la plus forte teneur en acide ascorbique tout en conservant plus longtemps les attributs qualitatifs (SS, AT et masse fraîche) et la teneur en acide ascorbique. Les fruits au stade immature ont présenté les valeurs les plus élevées des chlorophylles A et B, et cette étape est également recommandée pour l'extraction de ces bio-constituants. Conclusion. Le stade de récolte recommandé du camu-camu est le stade semi-mature, lorsque le fruit présente une meilleure qualité et une durée de conservation plus grande, et conserve les valeurs nutritionnelles souhaitées plus longtemps.

Mots clés : Brésil / forêt d'Amazonie / camu-camu / Myrciaria dubia / acide ascorbique / qualité des fruits / stade de mûrissement / gestion de la conservation

^ Corresponding author: luizagrigio@hotmail.com 


\section{Introduction}

The Amazon Rainforest presents several fruit species with great economic potential, especially camu-camu (Myrciaria dubia (Kunth) Mc Vaugh), also known as "caçari", "araçá d'água" or "sarão" [1]. This fruit species belongs to the Myrtaceae family, and is native to the lowlands and lakes of the region. Its occurrence is common on the banks of rivers and "igarapes" (small navigable rivers in the Amazon region) in the state of Roraima. Camu-camu is found in 8 of the 15 cities of Roraima: Amajari, Boa Vista, Bonfim, Cantá, Caracaraí, Caroebe, Normandia and Rorainópolis [2].

The plant is a shrub that reaches $3-8 \mathrm{~m}$ height, and may present several branches. Stems are hard but flexible; leaves are simple and opposed, and may be ovate, elliptic or lanceolate, 4 to $11 \mathrm{~cm}$ in length, and 2 to $4 \mathrm{~cm}$ in width. The flowers may appear individually or in the form of inflorescence, and are found in the axils of leaves in the whole length of the upper branches [3].

The fruit is bacaceous, globous, with a fleshy (gelatinous), whitish mesocarp, citric acid flavor, pale-green peel when immature, dark-red to black purple peel when mature, 1.4 to $2.7 \mathrm{~cm}$ in height, 1.6 to $3.1 \mathrm{~cm}$ in diameter, and with a mean weight of $8.4 \mathrm{~g}$. It presents 1 to 4 kidney-shaped seeds per fruit, with fibrils on the surface. The fruit has good agronomic, technological and nutritional traits $[4,5]$.

An increasing number of non-traditional species are being used by the local Brazilian populations, mainly due to the great exploitation potential for the market of in natura or industrialized products [6]. The increase in the economic exploitation of products and by-products of some fruit trees has been assigned to the increasing interest of the consumers in a wholesome diet [7]. The growing interest in camu-camu fruit is mainly due to its vitamin $\mathrm{C}$, or ascorbic acid content, the mean values of which in some fruits in the eastern area of Roraima range from $3,571-7,355 \mathrm{mg} 100 \mathrm{~g}^{-1}$ fresh pulp $[8,9]$. This high ascorbic acid content found in camu-camu fruits is one of the main quality attributes of its commercial marketing, since it helps combat and prevent free radicals, increasing immunological resistance and delaying early or natural aging [10]. On the other hand, one of the factors which contribute to the restriction of its consumption is the very acid and astringent flavor of the pulp, and the bitterness of the peel, indicating the need for research into better uses for this fruit.

Camu-camu has typical climacteric fruit behavior, and its maturation process continues after the harvest of the physiologically mature fruit [11]. Studies show that the highest ascorbic acid content was found in fruits harvested at 88 days after anthesis, which decreases in the subsequent periods, when fruits are completely red [12]. It was also found that for camucamu storage at different maturation stages, the more mature the fruits, the higher the ascorbic acid content [11].

The vitamin $\mathrm{C}$ concentration and stability differ according to the species, maturation stage, time and temperature of processing, $\mathrm{pH}$, and presence of oxygen and enzymes. Its degradation can also occur during fruit processing and/or storage [1]. Although there is a lack of information about harvest and maturation indicators of camu-camu fruit and its shelf life, some important traits should be taken into account when selecting the ideal harvest time, which varies according to the peel coloration during maturation (from pale green, when immature, to dark red or dark purple, when mature).

In this context, the present work was carried out with the purpose of determining the best harvest time and quality of native camu-camu fruits during storage.

\section{Materials and methods}

\subsection{Plant material used}

The camu-camu fruits used in the experiment were harvested from healthy native adult plants, of about 10 years of age, with no symptoms of nutritional deficiency, water stress, or signs of disease and/or pest attacks, located on the banks of Morena Lake, in the city of Cantá, state of Roraima $\left(02^{\circ} 27^{\prime} 45^{\prime \prime} \mathrm{S}, 60^{\circ} 50^{\prime} 14^{\prime \prime} \mathrm{W}\right)$.

\subsection{Fruit sampling and preparation}

Harvesting was carried out in February, 2012. Afterward, fruits were carefully transported in plastic boxes to the postharvest laboratory of Embrapa Roraima, where they were washed, selected for the absence of damage, and rinsed using $0.02 \%$ sodium hypochlorite $(\mathrm{NaClO})$ for $30 \mathrm{~min}$.

Afterward, fruits were classified according to the maturation stage, based on the peel color: immature (completely green peel); semi-mature (fruits with about $50 \%$ green and $50 \%$ purple peel); and mature (completely purple peel). Each coloration or maturation stage corresponds, respectively, to 60 , 81 and 102 days after anthesis [13]. After classification, fruits were stored in controlled laboratory conditions, in order to allow natural maturation, at $22 \pm 2{ }^{\circ} \mathrm{C}$ and $70 \pm 3 \%$ relative humidity (RH).

The experiment consisted of a completely randomized block design, in a factorial scheme $(3 \times 8)$, with three replications, constituting three different maturation stages (immature, semi-mature and mature), and eight days of storage. Each replication was composed of 30 fruits (approximately $300 \mathrm{~g}$ ).

Fruits were analyzed every day, weighed for loss of fresh mass verification, and, after seed removal, the remaining material (pulp + peel) was mashed and homogenized in a mixer in order to perform the analysis.

\subsection{Physical measurements}

On the day of the experiment's installation, also called day zero, all samples were weighed. The following day, and every other day of evaluation, the samples were weighed again to check the percentage of fresh mass loss by comparing the final weight with the initial weight of each sample. The results were expressed as \% of fresh mass loss [14].

The $\mathrm{pH}$ (potential of hydrogen) was measured with a $\mathrm{pH}-$ meter [14], by immersing the electrode in each processed sample. 


\subsection{Soluble solids (SS), titratable acidity (TA) and the maturation index (SS:TA)}

The soluble solid content was determined by using a portable refractometer (Biobrix ${ }^{\circledR}$, model ATC 104-D). Analyses were performed using the homogeneous filtrate of the mashed material, obtained by its separation from the solid parts by filtration, and results were expressed as ${ }^{\circ}$ Brix [14].

Titratable acidity was measured by using $10 \mathrm{~g}$ of the homogenized sample diluted in $100 \mathrm{~mL}$ distilled water, plus 2 drops of phenolphthalein solution, in titration of a solution of $0.1 \mathrm{~N}$ sodium hydroxide, expressed as g citric acid $100 \mathrm{~g}^{-1}$ pulp [14].

The maturation index was calculated by the ratio SS:TA.

\subsection{Estimated value of ascorbic acid (AA)}

The method is based on the reduction of the dye 2,6dichlorophenolindophenol (DCPIP) by the acidic solution of ascorbic acid. Ten $\mathrm{g}$ of the sample were diluted in $10 \mathrm{~mL}$ of oxalic acid, filtrated and titrated with Tillmans solution. The reaction was fast, and the final change was indicated by the dye, which in an acidic environment, and once fully oxidized by the ascorbic acid, changes to a vivid pink color. The results were expressed as mg ascorbic acid $100 \mathrm{~mL}^{-1}$ sample [14].

\subsection{Measurement of chlorophyll contents}

The determination of chlorophyll A and B contents was carried out by spectrophotometry, with readings at $663 \mathrm{~nm}$ and $647 \mathrm{~nm}$, respectively, and both results expressed as $\mu \mathrm{g} 100 \mathrm{~g}^{-1}$ fresh pulp $[15,16]$.

\subsection{Statistics}

All data obtained were subjected to analysis of variance by the F-test at 5\%, and analysis of polynomial regression, using the SISVAR program [17].

\section{Results and discussion}

The interaction (maturation stages $\mathrm{x}$ days of storage) presented a significant effect by the F-test at $5 \%$ of probability for all the tested variables.

Regarding the $\mathrm{pH}$ and the maturation index, no adjustments were required after regression for the tested models. The mean values for the $\mathrm{pH}$ observed during the experiment were 3.29, 3.32 and 3.34 for immature, semi-mature and mature harvested fruits, respectively. These values are higher than those observed in another study [17], in which a mean value of 2.44 was found. The fact that the pulp and peel (processed and homogenized) were used in the chemical analysis is a possible cause of the high $\mathrm{pH}$ values observed in this study.

The maturation index given by the SS:TA ratio calculated during the experiment had the following mean values: 1.59 ,

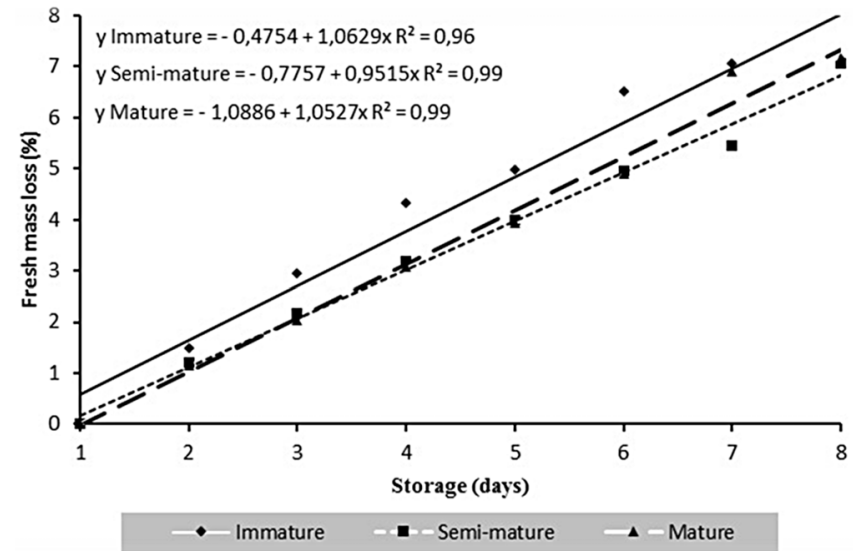

Figure 1. Evolution of fresh mass loss in camu-camu fruits harvested at different maturation stages and stored at $22{ }^{\circ} \mathrm{C}$ and $70 \%$ relative humidity (RH).

1.72 and 1.75 for immature, semi-mature and mature fruits, respectively. For more advanced maturation stages of camucamu fruit, higher values were observed [13]. This can be confirmed by the camu-camu behavior observed in this study, since higher soluble solid content and lower fruit acidity were found when the fruit was more mature. This corroborates other results in the literature [11].

As expected, the fresh mass loss presented increasing linear curves for all maturation stages, indicating increasing values during the experiment. The highest mean of fresh mass loss was observed at the immature stage, followed by the mature and semi-mature stages. The other maturation stages presented approximately $7 \%$ fresh mass loss at the end of the experiment (figure 1). Similar results were found for camu-camu fruits harvested at different maturation stages [11,19]. The authors verified that fresh mass loss was greater in more immature fruits than in more mature fruits, justified by the increased respiration and transpiration rates of more greenish fruits.

For soluble solids, similar increasing behavior was observed for all maturation stages, followed by a decrease. As expected, the more mature the camu-camu fruit, the higher the sugar content. The maximum value of soluble solids in mature fruits $\left(7.86^{\circ} \mathrm{Brix}\right)$ was observed at four days of storage, whereas for the semi-mature fruits $\left(7.43^{\circ} \mathrm{Brix}\right)$ and immature fruits $\left(7.28^{\circ} \mathrm{Brix}\right)$, these maximum values were observed on the sixth and fifth days of storage, respectively (figure 2 ). The maximum values observed in this study were approximately $20 \%$ higher than those reported in another study [1]. However, an increase in the soluble solid content is closely linked to fresh mass loss during storage. This is due to water loss, which is related to the concentration of the sugar content. Studies carried out during the storage of guavas also attributed the increase in the soluble solid content to fresh mass loss [20]. After the increase in the soluble solid content, there was a decrease in these values during the evolution of the fruit maturation stage, possibly due to the use of these compounds in the respiration process.

The acidity values presented an initial increase for all maturation stages, similar to that in the soluble solid contents, probably due to fresh mass loss, which concentrated the 


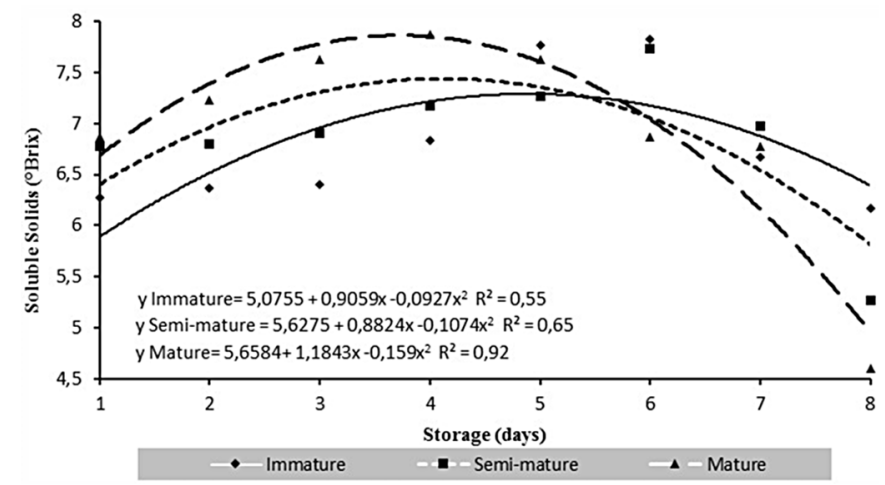

Figure 2. Soluble solid (SS) content of camu-camu fruits harvested at different maturation stages and stored at $22{ }^{\circ} \mathrm{C}$ and $70 \%$ relative humidity $(\mathrm{RH})$.

amount of these acids in the pulp. The fruits harvested at the

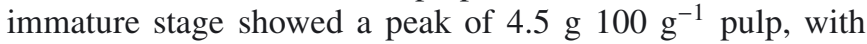
higher values on the seventh day of evaluation. This result was possibly due to an increase in fruit dehydration. Semi-mature and mature fruits showed maximum peaks of 4.14 and $4.17 \mathrm{~g}$ $100 \mathrm{~g}^{-1}$ pulp on the sixth day of evaluation. This increment may be related to the more advanced maturation stage of these fruits, when compared with fruits harvested at the immature stage, which had a peak of high citric acid content after the sixth day of evaluation (figure 3), followed by a decrease. Organic acids serve as an energy source for the metabolic transformations that occur in plant tissues [21].

The amount of citric acid found in camu-camu fruits was similar to those reported in the literature [23]. However, in these cited studies, only the pulp was analyzed, which explains values almost two times lower, indicating that a high amount of acids is also present in the peel of the fruits [24]. This explains the high values found in the present study, when compared with other work.

Immature fruits showed an increase in the estimated value of ascorbic acid during the experiment, with a high peak value of $5,781 \mathrm{mg} 100 \mathrm{~mL}^{-1}$ pulp on the $7^{\text {th }}$ day of storage, followed by a decrease (figure 4). This increase can be linked to the metabolic compound synthesis, which is the precursor of the ascorbic acid [11]. On the other hand, the decrease is explained by the oxidation of these acids, arising from changes in the maturation stage, and from the natural senescence process of the fruit.

Fruits harvested at the immature and mature stages presented an increase in the values of the ascorbic acid, which showed the lowest peak at the beginning of the experiment; 4,975 and 4,426 mg $100 \mathrm{~mL}^{-1}$ pulp, respectively. However, fruits harvested at the semi-mature stage had the highest amounts of ascorbic acid $\left(6,762 \mathrm{mg} 100 \mathrm{~mL}^{-1}\right.$ pulp) at the end of the experimental period, and these values were higher than those found in another study [8] for fruits in the eastern region of the state of Roraima. The highest value was 6,112 mg $100 \mathrm{~g}^{-1}$ fresh pulp, which was lower than those observed by [9] in camu-camu fruits in the southern region of Roraima. The high content of ascorbic acid observed in the present study is due to the fact that the pulp and peel were evaluated together. Fruits harvested at the immature and mature stages showed,

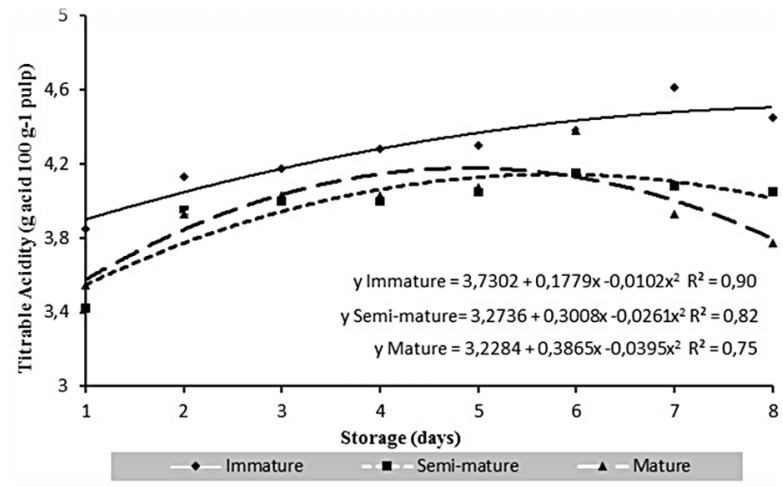

Figure 3. Titratable acidity (TA) content in camu-camu fruits harvested at different maturation stages and stored at $22{ }^{\circ} \mathrm{C}$ and $70 \%$ relative humidity $(\mathrm{RH})$.

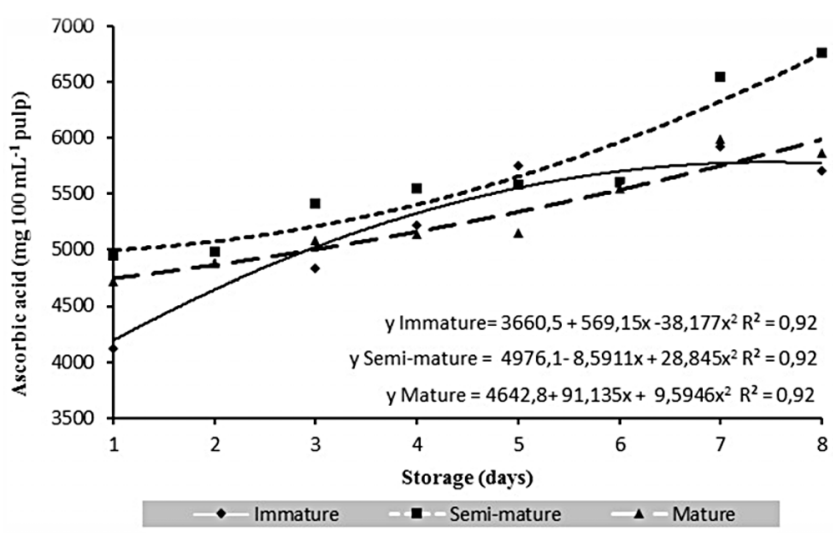

Figure 4. Ascorbic acid (AA) content in camu-camu fruits harvested at different maturation stages and stored at $22{ }^{\circ} \mathrm{C}$ and $70 \% \mathrm{RH}$.

on the fifth and seventh days of evaluation, respectively, max-

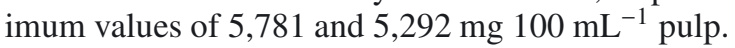

According to the literature, and taking into account that ascorbic acid is the main component explored in this fruit, a wide range of information was found on the best harvest time for camu-camu fruit. Some authors reported a high content of ascorbic acid in the pulp and peel when fruits presented 85\% red-colored peel; on the other hand, other studies found that the ascorbic acid content is higher when the fruit has purple peel and pink pulp [12,25]. Other authors who also evaluated camu-camu fruit harvested at different maturation stages reported higher ascorbic acid contents in green or immature fruits, approximately $2,280 \mathrm{mg} 100 \mathrm{~mL}^{-1}$ pulp [26]. However, the values observed in the present study are much higher.

There are studies in which high ascorbic acid contents were detected in fruits harvested at the semi-mature stage [27], corroborating the results found in the present study. Possibly, genetic variation, environmental factors [28] and other compounds with reducing activity may have significantly influenced the content reported in this work, and the different results observed in several studies.

Regarding chlorophyll A content, the fruits harvested at the immature stage presented the highest levels throughout the storage period. The peak of high chlorophyll A content for the these fruits was observed on the fourth day of evaluation 


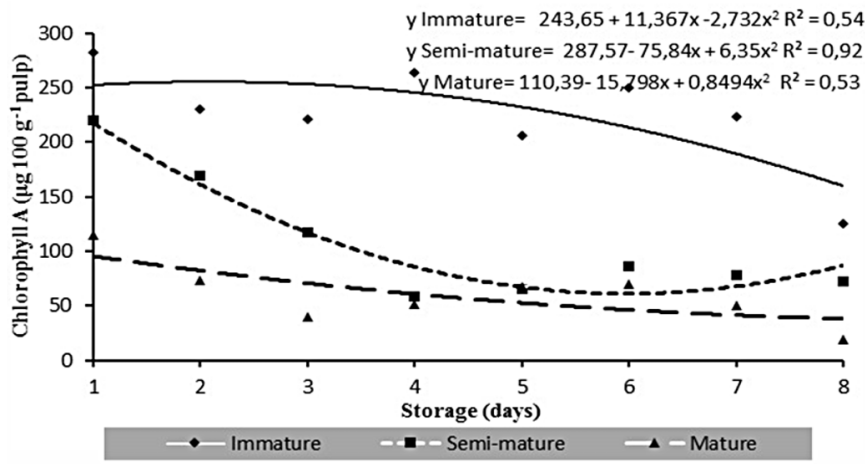

Figure 5. Chlorophyll A content in camu-camu fruits harvested at different maturation stages and stored at $22{ }^{\circ} \mathrm{C}$ and $70 \%$ relative humidity (RH).

(255 $\mu \mathrm{g} 100 \mathrm{~g}^{-1}$ pulp), followed by semi-mature and mature fruits, which presented minimum peaks at the end of the experiment, i.e., 61 and $37 \mu \mathrm{g} 100 \mathrm{~g}^{-1}$ pulp, respectively. From these results, it is concluded that the more developed the maturation stage, the lower the chlorophyll content in camu-camu fruits (figure 5). During fruit maturation, there is natural chlorophyll degradation and green color loss, due to the appearance of new colors, resulting from carotenoid and anthocyanin biosynthesis [21], which explains the chlorophyll A degradation in more mature fruits.

Similar behavior was observed when evaluating the chlorophyll B content, which degraded with the development of fruit maturation. Thus, immature fruits also showed the highest chlorophyll B content, followed by semi-mature and mature fruits (figure 6). During the evaluation period, degradation of chlorophyll B was detected in all fruits during storage, indicating the loss of this compound and the formation of new pigments, resulting from the biosynthesis of carotenoids and anthocyanins. Chlorophyll degradation can be influenced by several factors, including $\mathrm{pH}$ changes, presence of acidic components and increase in oxidative processes, as well as the action of chlorophyllase inherent in the natural maturation process [29]. Besides the natural maturation process, it is possible that the high acid content present in camu-camu fruit influenced the chlorophyll content during the storage period.

There are scientific reports in which the total chlorophyll content (chlorophyll A + chlorophyll B) in camu-camu fruits was not detected [6]. In the present study, only chlorophyll B was not detected from the third day of storage for mature fruits possibly due to the maturation stage of the tested fruits.

\section{Conclusion}

The highest ascorbic acid content was found in fruits at the semi-mature stage. At this stage, better conservation of the quality attributes (SS, TA and lower fresh mass loss) was also observed, giving them a longer shelf life. Chlorophyll A and $\mathrm{B}$ pigments were higher in greenish fruit, and this stage is the most suitable for obtaining these biocompounds. The best harvest time for camu-camu fruit is at the semi-mature stage, since

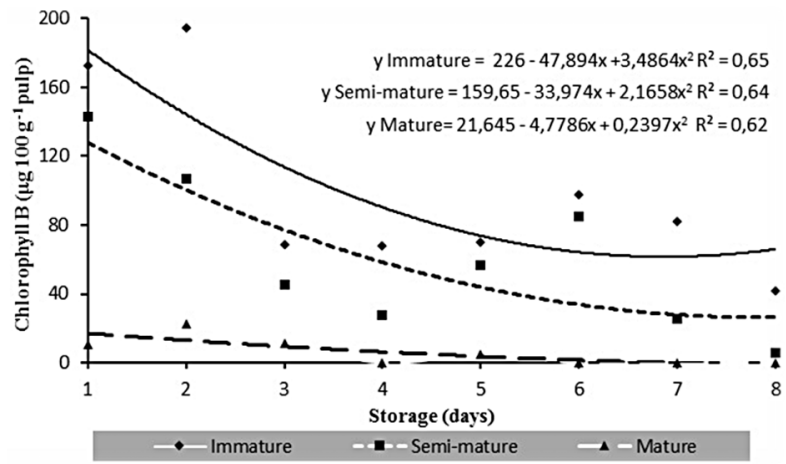

Figure 6. Chlorophyll B content in camu-camu fruits harvested at different maturation stages and stored at $22{ }^{\circ} \mathrm{C}$ and $70 \%$ relative humidity (RH).

it presents higher quality, provides a longer shelf life, and conserves the good quality attributes for longer.

\section{References}

[1] Maeda R.N., Pantoja L., Yuyama L.K.O., Chaar J.M., Estabilidade de ácido ascórbico e antocianinas em néctar de camu-camu (Myrciaria dubia (H. B. K.) Mc Vaugh), Ciência e Tecnologia de Alimentos, 27 (2007) 313-316.

[2] Carvalho A.S., Ocorrência, distribuição geográfica e estudo fenológico de camu-camuzeiro (Myrciaria dubia (H.B.K.) Mc Vaugh) no estado de Roraima. Universidade Federal de Roraima, Boa Vista, Brasil, Dissertação, 2012, 79 p.

[3] Yuyama K., Yuyama L.K.O., Valente J.P., Silva A.C., Aguiar J.P.L., Flores W.B.C., Lima, C.G.B.C., Camu-camu. Jaboticabal: FUNEP, São Paulo, 2010.

[4] Yuyama K.A., cultura de camu-camu no Brasil, Revista Brasileira de Fruticultura 33 (2011) i-ii.

[5] Maeda R.N., Pantoja L., Yuyama L.K.O., Chaar J.M., Determinação da formulação e caracterização do néctar de camu-camu (Myrciaria dubia Mc Vaugh), Ciência e Tecnologia de Alimentos 26 (2006) 70-74.

[6] Rufino M.doS.M., Propriedades funcionais de frutos brasileiros tropicais não tradicionais. Universidade Federal Rural do SemiÁrido, Mossoró, Brasil, Thesis, 2008, 263 p.

[7] Yahia E.M., The contribution of fruit and vegetable consumption to human health, in: Rosa L.A., Alvarez-Parrilla E., Gonzalezaguilara G.A. (Eds.), Fruit and vegetable phytochemicals: chemistry, nutritional value and stability, Hoboken: WileyBlackwell, 2010, pp. 3-51.

[8] Yuyama K., Aguiar J.P.L., Yuyama, L.K.O., Camu-camu: um fruto fantástico como fonte de vitamina C, Acta Amazônica. 32 (2002) 169-174.

[9] Chagas E.A., Lozano R.M.B., Bacelar-Lima C.G., Garcia M.I.G., Oliveira J.V., Souza O.M., Morais B.S., Chagas P.C., Araújo M.C.R., Variabilidade intraespecífica de frutos de camucamu em populações nativas na Amazônia Setentrional, Crop Breed. Appl. Biotechnol. 2015 (No Prelo).

[10] Santos J.C.dos., Santos A.P.dos., Rocha C.I.L. da, Estrutura da cadeia produtiva de camu-camu no Brasil, Relatório Final de projeto. Belém: CPATU, 2009, 35 p.

[11] Pinto P.M., Jacomino A.P., Da Silva S.R., Andrade C.A.W., Ponto de colheita e maturação de frutos de camucamu colhidos em diferentes estádios, Pesquisa Agropecuária Brasileira, 48 (2013) 605-612. 
[12] Neves L.C., Silva V.X., Pontis J.A., Flach A., Roberto S.R., Bioactive compounds and antioxidant activity in pre-harvest camu-camu [Myrciaria dubia (H.B.K.) Mc Vaugh] fruits, Sci. Hortic. 186 (2015) 223-229.

[13] Neves L.C., Silva V.X., Chagas E.A., Bacelar-Lima C.G., Roberto S.R., Determining the harvest time of camu-camu [Myrciaria dubia (H.B.K.) McVaugh] using measured preharvest attributes, Sci. Hortic. 186 (2015) 15-23.

[14] I.A.L. - INSTITUTO ADOLFO LUTZ (SÃO PAULO). Métodos físico-químicos para análise de alimentos, São Paulo: Instituto Adolfo Lutz, 2008.

[15] Linder S., A proposal for the use of standardized methods for chlorophyll determinations in ecological and ecophysiological investigations, Physiol. Plant. 32 (1974) 154-56.

[16] Whitham F.H., Blaydes D.F., Devlin R.M., Experiments in plant physiology, New York: D. Van Nostrand Company, 1971.

[17] Ferreira D.F., Sisvar: Versão 5.1 (Build 72), DEX/UFLA, 2007.

[18] Akter M.S., Oh S., Eun J.B., Ahmed M., Nutritional composition and health promoting phytochemicals of camu-camu (Myrciaria dubia) fruit: A review, Food Res. Int. 44 (2011) 1728-1732.

[19] Andrade J.S., Silveira J.S., Ferreira S.A.N., Brasil J.E.B., Effects of ripening stage and environment conditions on stored postharvest camucamu (Myrciaria dubia McVaugh) fruits, Acta Hortic. 64 (2010) 423-429.

[20] Jacomino A.P., Sarantópoulos C.D.I.de L., Sigrist J.M.M., Kluge R.A., Minami K., Armazenamento de goiabas 'Kumagai' sob diferentes temperaturas de refrigeração, Braz. J. Food Technol. 1 (2000) 165-169.

[21] Chitarra M.I.F., Chitarra A.B., Pós-colheita de frutos e hortaliças: fisiologia e manuseio, Lavras, 2005.
[22] Cavalini F.C. Índices de maturação, ponto de colheita e padrão respiratório de goiabas 'Kumagai' e 'Paluma', Escola Superior de Agricultura Luiz de Queiroz, Piracicaba, São Paulo, Brasil, Dissertação, 2004, 69 p.

[23] Maeda R.N., Andrade J.S., Aproveitamento do camu-camu (Myrciaria dubia) para produção de bebida alcoólica fermentada, Acta Amazônica 33 (2003) 489-498.

[24] Vieira V.B., Rodrigues J.B., Brasil C.C.B., Rosa C.S.da., Produção, caracterização e aceitabilidade de licor de camucamu (Myrciaria dúbia), Alimentos e Nutrição 21 (2010) 519522.

[25] Yuyama K., Sousa E.C.C., Crescimento de mudas de camucamu com o uso de adubação mineral e orgânica em quatro tipos de solos da Amazônia, in: Jornada paulista de plantas medicinais, 5, Natureza, Ciência e Comunidade, Botucatu, São Paulo, 2001, p. 57.

[26] Chirinos R., Galarza J., Betalleluz-Pallardel I., Pedreschi R., Campos D., Antioxidant compounds and antioxidant capacity of Peruvian camu-camu (Myrciaria dubia (H.B.K) Mc Vaugh) fruit at different maturity stages, Food Chem. 120 (2010) 10191024.

[27] Pinedo P.M., Delgado V.C., Farroñay P.R., Dell Castillo T.D., Iman C.S., Villacrés V. J., Faching M.L., Oliva C.C., Abanto R.C., Bardales L.R., Vega V.R., Camu-camu (Myrciaria dubia, Myrtaceae), aportes para su aprovechamiento sostenible en la Amazonia peruana. Instituto de la Amazonia Peruana. Lima, 2010.

[28] Pinedo P.M., Análisis de correlación y heredabilidad en el mejoramiento genético del camu-camu, Scientia Agropecuaria 1 (2012) 23-28.

[29] Wills R., McGlasson B., Graham D., Joyce D., Postharvest: an introduction to the physiology and handling of fruit, vegetables and ornamentals, New York, 1998.

Cite this article as: Maria Luiza Grigio, Edvan Alves Chagas, Maria Fernanda Berlingieri Durigan, Ataiza de Andrade Sousa, Adamor Barbosa Mota Filho, Pollyana Cardoso Chagas. Determination of harvest time and quality of native camu-camu fruits (Myrciaria dubia (Kunth) Mc Vaugh) during storage. Fruits 71 (2016) 373-378. 